\title{
THE DIFFUSING CAPACITY OF THE LUNGS IN PATIENTS WITH MITRAL STENOSIS STUDIED POST-OPERATIVELY ${ }^{1}$
}

\author{
By R. L. RILEY, C. J. JOHNS,2 G. COHEN, J. E. COHN, D. G. CARROLL, AND \\ R. H. SHEPARD ${ }^{3}$ \\ (From the Departments of Environmental Medicine and of Medicine, The Johns Hopkins \\ University and Hospital, Baltimore, Md.)
}

(Submitted for publication November 2, 1955 ; accepted May 24, 1956)

The fact that morphological changes occur in the lungs of patients with mitral stenosis has been generally accepted since 1936 when Parker and Weiss described thickening of the capillary basement membrane, scarring and probable loss of capillaries (1). These findings have been confirmed and extended by others $(2,3)$, yet there is no agreement regarding the physiological and clinical significance of the pulmonary lesions. Because of their location in relation to vascular structures, one would expect that such lesions might interfere with the flow of blood through the lungs or with the diffusion of gases across the pulmonary membrane. Hemodynamic studies by a number of different workers have demonstrated an increase in pulmonary vascular resistance in patients with mitral stenosis (4-10). This paper deals with studies of the diffusion of gases across the pulmonary membrane in a group of patients on whom mitral valvulotomy had been performed.

The diffusing capacity for oxygen is the number of $\mathrm{ml}$. of oxygen diffusing across the pulmonary membrane per minute in response to a mean difference of $1 \mathrm{~mm}$. $\mathrm{Hg}$ in the partial pressure of oxygen on the two sides of the membrane. It is a function of the thickness, physicochemical structure and area of the surface across which diffusion takes place. The area is related to the area of the walls of all capillaries which are actively involved in gas exchange. Capillaries are not included if

\footnotetext{
1 This study was aided by a contract between the Office of Naval Research, Department of the Navy, and The Johns Hopkins University (NR 112-101) and by funds provided under contract AF 18 (600)-435 with the USAF School of Aviation Medicine, Randolph Field, Texas.

2 Fellow of the National Foundation for Infantile Paralysis.

${ }^{3}$ Medical Research Fellow of the National Tuberculosis Association. (Administered by the National Research Council, July 1953 to July 1955.)
}

they are not perfused with blood and do not take part in gas exchange. This qualification is of great importance since recent studies suggest that at rest only a fraction of the total capillary bed is perfused (11). With increase in cardiac output in response to exercise the diffusing capacity approaches a maximal value, probably because an increasing fraction of the total capillary bed takes part in gas exchange.

In an earlier study in this laboratory low diffusing capacities were demonstrated pre-operatively in some patients with mitral stenosis studied at rest (12). It was impossible to decide whether these low values indicated morphological changes in the diffusing surface or simply a smaller than usual fraction of perfused capillaries. The present study was designed to minimize this difficulty by dealing only with patients who could tolerate the combined stress of exercise and hypoxia, a combination which is effective in producing maximal values for diffusing capacity in normal persons. The finding of diffusing capacities during exercise which approach the predicted normal values for maximal diffusing capacity would provide evidence against the presence of extensive structural lesions involving the pulmonary membrane. Low results might be equivocal because of uncertainties regarding the fraction of the total capillary bed perfused, but very low values would suggest the presence of extensive structural changes.

\section{CLINICAL MATERIAL AND METHODS}

The subjects were 14 patients who had had incapacitating mitral stenosis of long standing but who had improved sufficiently following mitral valvulotomy to tolerate the combined stress of exercise and hypoxia. They were believed to have little or no mitral insufficiency on the basis of the clinical examination and the surgeon's impression at operation. Vital statistics and clinical information are listed in Table I. The pre-operative studies performed at rest on 5 of these patients (M. C., F. G., 
TABLE I

Physical characteristics of patients and pre-operative clinical data

\begin{tabular}{|c|c|c|c|c|c|c|c|c|c|c|}
\hline \multirow[b]{2}{*}{ Subject } & \multirow[b]{2}{*}{ Sex } & \multirow[b]{2}{*}{ Age } & \multirow{2}{*}{$\begin{array}{c}\mathrm{Ht} . \\
(\mathrm{cm.})\end{array}$} & \multirow{2}{*}{$\begin{array}{c}\mathrm{BSA}_{(s q .}^{*} \text {. } \\
\text {. })\end{array}$} & \multicolumn{6}{|c|}{ Years since onset of } \\
\hline & & & & & ARFT & Dyspnea & Failure & Digitalis & Hemoptysis & Fibrillation \\
\hline $\begin{array}{l}\text { N. R. } \\
\text { F. G. } \\
\text { D. E. } \\
\text { J. W. } \\
\text { W. L. } \\
\text { D. B. } \\
\text { E. S. } \\
\text { J. A. } \\
\text { G. B. }\end{array}$ & $\begin{array}{l}\mathbf{F} \\
\mathbf{F} \\
\mathbf{F} \\
\mathbf{M} \\
\mathbf{F} \\
\mathbf{F} \\
\mathbf{M} \\
\mathbf{M}\end{array}$ & $\begin{array}{l}46 \\
25 \\
31 \\
38 \\
37 \\
40 \\
39 \\
24 \\
24\end{array}$ & $\begin{array}{l}163 \\
162 \\
187 \\
160 \\
178 \\
175 \\
160 \\
183 . \\
183\end{array}$ & $\begin{array}{l}1.74 \\
1.65 \\
1.99 \\
1.45 \\
1.98 \\
1.89 \\
1.58 \\
2.07 \\
1.83\end{array}$ & $\begin{array}{c}31 \\
11 \\
28 \\
\text { None } \\
31 \\
30 \\
\text { None } \\
12 \\
\text { None }\end{array}$ & $\begin{array}{l}2 \\
3 \\
3 \\
4 \\
8 \\
5 \\
5 \\
3 \\
4\end{array}$ & $\begin{array}{c}1 \\
6 / 12 \\
\text { None } \\
2 \\
\text { None } \\
2 / 12 \\
1 / 12 \\
1 \\
\text { None }\end{array}$ & $\begin{array}{c}11 \\
2 \\
\text { None } \\
4 \\
3 \\
\text { None } \\
1 / 12 \\
1 \\
\text { None }\end{array}$ & $\begin{array}{c}2 \\
1 / 12 \\
2 \\
\text { None } \\
7 \\
2 / 12 \\
7 / 12 \\
9 / 12 \\
4\end{array}$ & $\begin{array}{c}1 \\
6 / 12 \\
1 / 12 \\
\text { None } \\
\text { None } \\
\text { None } \\
\text { None } \\
8 \\
\text { None }\end{array}$ \\
\hline $\begin{array}{l}\text { M. C. } \\
\text { T. P. } \\
\text { L. E. } \\
\text { M. P. } \\
\text { R. D. }\end{array}$ & $\begin{array}{l}\mathbf{F} \\
\mathbf{M} \\
\mathbf{F} \\
\mathbf{F} \\
\mathbf{F}\end{array}$ & $\begin{array}{l}22 \\
39 \\
35 \\
27 \\
39\end{array}$ & $\begin{array}{l}157 \\
170 \\
155 \\
151 \\
159\end{array}$ & $\begin{array}{l}1.47 \\
1.80 \\
1.47 \\
1.34 \\
1.48\end{array}$ & $\begin{array}{c}6 \\
30 \\
23 \\
18 \\
\text { None }\end{array}$ & $\begin{array}{c}11 / 12 \\
2 \\
3 \\
2 \\
7\end{array}$ & $\begin{array}{c}\text { None } \\
\text { None } \\
\text { None } \\
1 \\
2\end{array}$ & $\begin{array}{c}11 / 12 \\
11 / 12 \\
3 \\
10 / 12 \\
3\end{array}$ & $\begin{array}{c}2 / 12 \\
2 \\
6 \\
\text { None } \\
\text { None }\end{array}$ & $\begin{array}{c}\text { None } \\
\text { None } \\
\text { None } \\
\text { None } \\
1\end{array}$ \\
\hline
\end{tabular}

* BSA: body surface area.

† ARF: acute rheumatic fever.

J. A., L. E., and R. D.) were part of the previous report (12). Similar studies at rest have been reported by others $(5,13,14)$.

Studies of ventilation, of the distribution of blood and gas within the lungs and of diffusing capacity were performed. Vital capacity and maximal breathing capacity measurements were compared to the normal standards of Baldwin, Cournand, and Richards, as re-analyzed by Armstrong $(15,16)$. The distribution of blood and gas within the lungs was evaluated by means of the ratio of "dead space" to tidal volume and the ratio of "venous admixture" to total blood flow, according to a system of analysis which has been reported (17-19). The upper limit of normal for the ratio of "dead space" to tidal volume is considered to be .30 and for the ratio of "venous admixture" to total flow, .06 .

Diffusing capacity was determined by the method of Lilienthal, Riley, Proemmel, and Franke (20). The patients' exercise tolerance was not adequate to permit determinations at several different levels of work as can be done with normal subjects (11). Work was performed on a motor-driven treadmill at rates which on clinical grounds seemed as strenuous as the patients could safely tolerate at the lower level of oxygenation. The duration of exercise was 6 to 10 minutes. Every patient except one (R. D.) consumed oxygen at a rate in excess of $400 \mathrm{ml}$. per min. per sq. meter body surface, and all had diffusion gradients at the end of the alveolar capillaries $\left(P_{\Delta}{ }^{\bullet}-P_{c}{ }^{\bullet}\right)$ of $6 \mathrm{~mm} . \mathrm{Hg}$ or more. In every instance the arterial blood oxygen tension was $50 \mathrm{~mm}$. $\mathbf{H g}$ or below at the lower level of oxygenation.

The determinations of "dead space," "venous admixture" and diffusing capacity required simultaneous sampling of expired gas and arterial blood at two different levels of oxygenation. A value for mixed venous blood is also necessary, and simultaneous sampling of mixed venous blood would have been desirable theoretically but might have been dangerous during treadmill exercise.
Values for mixed venous blood at either extreme of the physiologic range were therefore assumed and a corresponding range for diffusing capacity calculated. The assumed values for oxygen saturation of mixed venous blood were such as to produce differences in saturation between the blood leaving the pulmonary capillaries and the mixed venous blood $\left(\mathrm{S}_{e}{ }^{\circ}-\overline{\mathrm{S}} \mathrm{v}\right)$ of 40 and 70 per cent during exercise and 25 and 50 per cent at rest. Since the saturation of the blood leaving the capillaries $\left(\mathrm{S}_{\circ}{ }^{\circ}\right)$ was approximately 80 per cent at the lower level of oxygenation, the assumed mixed venous blood values $(\overline{\mathrm{S}} v)$ were approximately 40 and 10 per cent, respectively, for the studies during exercise. They were approximately $\mathbf{5 5}$ and 30 per cent for the studies at rest. The range of values for diffusing capacity yielded by this procedure is sufficiently precise for the problems under consideration.

The values obtained for diffusing capacity were compared to the maximal values reported by Cohn, Carroll, Armstrong, Shepard, and Riley for normal men of different ages (21). Since adequate normal standards for women are not available, three-fourths of the value for a man of the same age and height was used in the case of female subjects. This procedure is consistent with the findings in the 9 normal women in the same age group whose maximal diffusing capacities have been determined in this laboratory to date. If the predicted normal value in any instance is taken to be 100 per cent, a given determination will be within one standard deviation if it falls within 19 per cent of the predicted normal, e.g., between 81 and 119 per cent.

\section{RESULTS}

In all of the tables the patients are arranged in order of decreasing diffusing capacity during exercise. The data of patients whose highest diffusing capacity during exercise was within 1 standard de- 
RILEY, JOHNS, COHEN, COHN, CARROLL, AND SHEPARD

TABLE' $\mathbf{I I}$

Ventilatory capacities and values related to blood-gas distribution in the lungs

\begin{tabular}{|c|c|c|c|c|c|c|c|}
\hline \multirow[b]{2}{*}{ Subject } & \multirow{2}{*}{$\begin{array}{l}\text { Months } \\
\text { post-op. }\end{array}$} & \multicolumn{2}{|c|}{ Vital capacity } & \multicolumn{2}{|c|}{ Maximal breathing capacity } & \multirow{2}{*}{$\begin{array}{l}\text { \% Dead space } \\
\mathrm{VD}^{\circ} / V_{T^{\circ}} \times 100\end{array}$} & \multirow{2}{*}{$\begin{array}{c}\text { Range of } \\
\% \text { venous } \\
\text { admixture } \\
\text { Qva/Qt } \times 100\end{array}$} \\
\hline & & $L$. & $\overline{\% N}{ }^{*}$ & L. min. & $\% N .^{*}$ & & \\
\hline N. R. & 41 & 2.58 & 96 & 67 & 82 & 30 & $3.5-2$ \\
\hline F. G. & 26 & 3.38 & 108 & 106 & 112 & 18 & $2-1$ \\
\hline D. E. & 55 & 5.70 & 129 & 155 & 114 & 26 & $3-2$ \\
\hline J.W. & $\begin{array}{r}6 \\
21\end{array}$ & $\begin{array}{l}3.75 \\
3.84\end{array}$ & $\begin{array}{l}133 \\
136\end{array}$ & $\begin{array}{r}89 \\
107\end{array}$ & $\begin{array}{l}102 \\
120\end{array}$ & $\begin{array}{l}26 \\
24\end{array}$ & $\begin{array}{r}1-0.5 \\
2.5-1.5\end{array}$ \\
\hline W. L. & $\begin{array}{l}24 \\
41\end{array}$ & $\begin{array}{l}5.95 \\
4.49\end{array}$ & $\begin{array}{l}145 \\
116\end{array}$ & $\begin{array}{l}177 \\
126\end{array}$ & $\begin{array}{l}136 \\
116\end{array}$ & $\begin{array}{l}26 \\
26\end{array}$ & $\begin{array}{l}3-1.5 \\
4-2.5\end{array}$ \\
\hline D. B. & 37 & 3.73 & 116 & 132 & 136 & 30 & $4.5-3$ \\
\hline E. S. & $\begin{array}{l}29 \\
42\end{array}$ & $\begin{array}{l}2.37 \\
2.20\end{array}$ & $\begin{array}{l}87 \\
81\end{array}$ & $\begin{array}{l}88 \\
62\end{array}$ & $\begin{array}{r}105 \\
75\end{array}$ & $\begin{array}{l}28 \\
28\end{array}$ & $\underset{5-3}{4-2.5}$ \\
\hline J. A. & $\begin{array}{r}4 \\
31\end{array}$ & $\begin{array}{l}4.32 \\
4.38\end{array}$ & $\begin{array}{l}95 \\
97\end{array}$ & $\begin{array}{l}128 \\
129\end{array}$ & $\begin{array}{l}87 \\
98\end{array}$ & $\begin{array}{l}22 \\
24\end{array}$ & $7.5-5$ \\
\hline G. B. & 25 & 4.45 & 99 & 117 & 87 & 32 & $1.5-1$ \\
\hline M. C. & 5 & 2.11 & 68 & & & 19 & $2.5-1.5$ \\
\hline T. P. & $\begin{array}{r}5 \\
9 \\
33\end{array}$ & $\begin{array}{l}3.67 \\
3.88 \\
4.08\end{array}$ & $\begin{array}{r}93 \\
99 \\
108\end{array}$ & $\begin{array}{l}148 \\
132 \\
147\end{array}$ & $\begin{array}{l}127 \\
113 \\
134\end{array}$ & $\begin{array}{l}22 \\
26 \\
35\end{array}$ & $\begin{array}{l}1-0.5 \\
4-2.5 \\
4-2.5\end{array}$ \\
\hline L. E. & 29 & 2.39 & 88 & 62 & 75 & 30 & $2-1$ \\
\hline M. P. & 11 & 2.39 & 83 & 87 & 100 & 39 & $3-1.5$ \\
\hline R. D. & $\begin{array}{l}11 \\
38\end{array}$ & $\begin{array}{l}2.12 \\
2.12\end{array}$ & $\begin{array}{l}74 \\
78\end{array}$ & $\begin{array}{l}87 \\
76\end{array}$ & $\begin{array}{l}88 \\
92\end{array}$ & $\begin{array}{l}31 \\
39\end{array}$ & $\begin{array}{r}7-4 \\
14-9\end{array}$ \\
\hline
\end{tabular}

* Predicted normal values for vital capacity and maximal breathing capacity decrease with age and therefore, in a given patient, the predicted normal values change when the studies are separated by a period of many months.

+ Values for $\%$ venous admixture are dependent upon the composition of the mixed venous blood and hence upon the assumed values for $S_{0}{ }^{0}-\bar{S} v$ (see text).

viation of the predicted normal maximal value appear above the horizontal line; the lower values are below the line. No helpful correlation between the pre-operative clinical information and the diffusing capacity during exercise is evident (Table I), and abnormalities in ventilatory capacities and in values related to blood-gas distribution in the lungs are not significantly correlated with abnormalities in diffusing capacity (Table II).

Diffusing capacities and related values are presented in Table III. Three of the 5 patients for whom serial data are available show increases in diffusing capacity during exercise over periods of 4, 15 and 27 months, but these changes are not beyond one standard deviation ( 19 per cent of the predicted normal maximal value). In a fourth patient (W. L.) a significant decrease in diffusing capacity occurred between 24 and 41 months postoperatively. In Figure 1 the range of diffusing capacity is shown for all post-operative studies during exercise. These data are plotted as percentage of the predicted normal maximal values and are shown in relation to the number of months after operation. Approximately half of the patients had diffusing capacities during exercise which were within 1 standard deviation of the predicted normal maximal values.

In the 6 patients for whom pre-operative studies at rest are reported, the diffusing capacity at rest was 24 per cent or less of the predicted normal maximal value. Normal standards for diffusing capacity at rest have not been defined clearly for the reason that the normal alveolar-capillary diffusion gradient at the end of the capillary $\left(\mathrm{P}_{\mathrm{A}^{\circ}}-\mathrm{P}^{\circ}\right.$ 
PULMONARY DIFFUSING CAPACITY IN MITRAL STENOSIS

TABLE III

Diffusing capacity and related values $\uparrow$

\begin{tabular}{|c|c|c|c|c|c|c|c|c|c|}
\hline Subject & $\begin{array}{l}\text { Months } \\
\text { post-op. }\end{array}$ & $\frac{\dot{V}_{O_{2}}}{M^{2}}$ & $\mathrm{PaO}_{2}$ & $\begin{array}{c}\text { Range } \\
\text { of } \\
P_{\mathbf{A}^{\circ}-P_{0}}\end{array}$ & $\begin{array}{c}\text { Range } \\
\text { of } \\
\mathbf{P}_{\mathbf{A}^{\circ}-}-\overline{\mathbf{P}}_{\mathbf{C}}\end{array}$ & $\begin{array}{c}\text { Assumed } \\
\text { range } \\
\text { Song } \\
\end{array}$ & $\begin{array}{c}\text { Pred. } \\
\text { max. } \\
\text { Do2 }\end{array}$ & $\begin{array}{c}\text { Range of } \\
\text { observed } \\
\text { Do2 }\end{array}$ & $\begin{array}{l}\text { Range of } \\
\% \text { pred. } \\
\text { max. Doz }\end{array}$ \\
\hline N. R. & 41 & 488 & 43 & $11-10$ & $21-27$ & $40-70$ & 31 & $40-31$ & $129-100$ \\
\hline F. G. & $-\frac{\frac{1}{2}^{*}}{26}$ & $\begin{array}{l}178^{*} \\
530\end{array}$ & $\begin{array}{l}32^{*} \\
36\end{array}$ & $\begin{array}{l}27^{*} \\
10\end{array}$ & $\begin{array}{l}30-34^{*} \\
18-22\end{array}$ & $\begin{array}{l}25-50^{*} \\
40-70\end{array}$ & $\begin{array}{l}40 \\
39\end{array}$ & $\begin{array}{r}9-8^{*} \\
49-40\end{array}$ & $\begin{array}{r}22-20^{*} \\
126-102\end{array}$ \\
\hline D. E. & 55 & 762 & 43 & 10 & $20-26$ & $40-70$ & 65 & $76-58$ & $117-89$ \\
\hline J.W. & 21 & $\begin{array}{l}422 \\
510\end{array}$ & $\begin{array}{l}50 \\
34\end{array}$ & $\begin{array}{r}7 \\
14\end{array}$ & $\begin{array}{l}20-26 \\
21-26\end{array}$ & $\begin{array}{l}40-70 \\
40-70\end{array}$ & $\begin{array}{l}34 \\
33\end{array}$ & $\begin{array}{l}31-24 \\
35-29\end{array}$ & $\begin{array}{r}91-71 \\
106-88\end{array}$ \\
\hline W. L. & $\begin{array}{l}24 \\
41\end{array}$ & $\begin{array}{l}470 \\
470\end{array}$ & $\begin{array}{l}43 \\
31\end{array}$ & $\begin{array}{r}6 \\
20\end{array}$ & $\begin{array}{l}16-20 \\
26-31\end{array}$ & $\begin{array}{l}40-70 \\
40-70\end{array}$ & $\begin{array}{l}56 \\
55\end{array}$ & $\begin{array}{l}59-47 \\
36-30\end{array}$ & $\begin{array}{r}105-84 \\
65-56\end{array}$ \\
\hline D. B. & $6^{6^{*}}$ & $\begin{array}{l}117^{*} \\
470\end{array}$ & $\begin{array}{l}47^{*} \\
44\end{array}$ & $11^{9^{*}}$ & $\begin{array}{l}14-19^{*} \\
22-28\end{array}$ & $\begin{array}{l}25-50^{*} \\
40-70\end{array}$ & $\begin{array}{l}40 \\
39\end{array}$ & $\begin{array}{l}16-11^{*} \\
40-32\end{array}$ & $\begin{array}{c}40-27^{*} \\
103-82\end{array}$ \\
\hline E.S. & $\begin{array}{l}29 \\
42\end{array}$ & $\begin{array}{l}464 \\
424\end{array}$ & $\begin{array}{l}46 \\
45\end{array}$ & $\begin{array}{c}11 \\
10-11\end{array}$ & $\begin{array}{l}23-30 \\
22-29\end{array}$ & $\begin{array}{l}40-70 \\
40-70\end{array}$ & $\begin{array}{l}32 \\
31\end{array}$ & $\begin{array}{l}32-25 \\
30-23\end{array}$ & $\begin{array}{r}100-78 \\
97-74\end{array}$ \\
\hline J. A. & $\begin{array}{c}-23^{*} \\
-1^{*} \\
4 \\
31\end{array}$ & $\begin{array}{l}149^{*} \\
197^{*} \\
442 \\
728\end{array}$ & $\begin{array}{l}47^{*} \\
38^{*} \\
40 \\
33\end{array}$ & $\begin{array}{c}15-14^{*} \\
20^{*} \\
8 \\
17\end{array}$ & $\begin{array}{l}27-32^{*} \\
27-31^{*} \\
17-21 \\
24-30\end{array}$ & $\begin{array}{l}25-50^{*} \\
25-50^{*} \\
40-70 \\
40-70\end{array}$ & $\begin{array}{l}68 \\
68 \\
67 \\
66\end{array}$ & $\begin{array}{l}11-9^{*} \\
15-13^{*} \\
51-42 \\
65-52\end{array}$ & $\begin{array}{l}16-13^{*} \\
22-19^{*} \\
76-63 \\
98-78\end{array}$ \\
\hline G. B. & 25 & 675 & 41 & 12 & $21-27$ & $40-70$ & 67 & $59-46$ & $88-69$ \\
\hline M. C. & $-1^{*}$ & $\begin{array}{l}147^{*} \\
498\end{array}$ & $\begin{array}{l}46^{*} \\
43\end{array}$ & $\begin{array}{c}19-18^{*} \\
14\end{array}$ & $\begin{array}{l}29-34^{*} \\
25-31\end{array}$ & $\begin{array}{l}25-50^{*} \\
40-70\end{array}$ & $\begin{array}{l}39 \\
39\end{array}$ & $\begin{array}{c}7-6^{*} \\
29-24\end{array}$ & $\begin{array}{l}18-15^{*} \\
74-61\end{array}$ \\
\hline T. P. & $\begin{array}{r}5 \\
9 \\
33\end{array}$ & $\begin{array}{l}470 \\
556 \\
586\end{array}$ & $\begin{array}{l}45 \\
45 \\
40\end{array}$ & $\begin{array}{c}20 \\
14 \\
20-19\end{array}$ & $\begin{array}{l}32-38 \\
26-32 \\
30-35\end{array}$ & $\begin{array}{l}40-70 \\
40-70 \\
40-70\end{array}$ & $\begin{array}{l}50 \\
50 \\
49\end{array}$ & $\begin{array}{l}26-22 \\
38-31 \\
35-30\end{array}$ & $\begin{array}{l}52-44 \\
76-62 \\
71-61\end{array}$ \\
\hline L. E. & $-\frac{1}{2 *}$ & $\begin{array}{l}128^{*} \\
403\end{array}$ & $\begin{array}{l}39^{*} \\
37\end{array}$ & $\begin{array}{c}16-15^{*} \\
19\end{array}$ & $\begin{array}{l}23-27^{*} \\
28-33\end{array}$ & $\begin{array}{l}25-50^{*} \\
40-70\end{array}$ & $\begin{array}{l}33 \\
32\end{array}$ & $\stackrel{8-7^{*}}{22-18}$ & $\begin{array}{l}24-21^{*} \\
69-56\end{array}$ \\
\hline M. P. & $\begin{array}{c}-1^{*} \\
11 \\
21^{*}\end{array}$ & $\begin{array}{c}99^{*} \\
403 \\
108^{*}\end{array}$ & $\begin{array}{l}40^{*} \\
37 \\
38^{*}\end{array}$ & $\begin{array}{l}23^{*} \\
19 \\
7^{*}\end{array}$ & $\begin{array}{l}29-34^{*} \\
31-36 \\
12-16^{*}\end{array}$ & $\begin{array}{l}25-50^{*} \\
40-70 \\
25-50^{*}\end{array}$ & $\begin{array}{l}34 \\
34 \\
33\end{array}$ & $\begin{array}{c}5-4^{*} \\
18-16 \\
12-9^{*}\end{array}$ & $\begin{array}{l}15-12^{*} \\
53-47 \\
36-27^{*}\end{array}$ \\
\hline R. D. & $\begin{array}{r}-1^{*} \\
-1^{*} \\
1^{*} \\
2^{*} \\
11^{*} \\
11 \\
38\end{array}$ & $\begin{array}{l}151^{*} \\
135^{*} \\
115^{*} \\
147^{*} \\
107^{*} \\
238 \\
360\end{array}$ & $\begin{array}{l}41^{*} \\
42^{*} \\
48^{*} \\
46^{*} \\
41^{*} \\
41 \\
42\end{array}$ & $\begin{array}{c}46-47^{*} \\
17-16^{*} \\
18-12^{*} \\
20-18^{*} \\
13-12^{*} \\
16 \\
26\end{array}$ & $\begin{array}{l}63-68^{*} \\
25-30^{*} \\
30-32^{*} \\
32-36^{*} \\
20-24^{*} \\
27-33 \\
40-47\end{array}$ & $\begin{array}{l}25-50^{*} \\
25-50^{*} \\
25-50^{*} \\
25-50^{*} \\
25-50^{*} \\
40-70 \\
40-70\end{array}$ & $\begin{array}{l}34 \\
34 \\
34 \\
34 \\
33 \\
33 \\
31\end{array}$ & $\begin{array}{c}3^{*} \\
8-6^{*} \\
6-5^{*} \\
6^{*} \\
8-7^{*} \\
13-11 \\
13-11\end{array}$ & $\begin{array}{c}9^{*} \\
24^{*} 18^{*} \\
18-15^{*} \\
18^{*} \\
24-21^{*} \\
39-33 \\
42-35\end{array}$ \\
\hline
\end{tabular}

* Indicates data obtained at rest.

$+\mathrm{V}_{\mathrm{O}_{2}} / M^{2}=\mathrm{O}_{2}$ consumption in ml. per minute S.T.P.D. (Standard temperature and pressure, dry) per square meter of body surface area.

$\mathrm{PaO}_{2}=$ arterial $\mathrm{PO}_{2}$ in $\mathrm{mm}$. $\mathrm{Hg}$.

$\mathrm{P}_{\mathbf{A}^{\circ}}-\overline{\mathrm{P}} \mathbf{c}=$ Mean alveolo-capillary oxygen tension gradient in $\mathrm{mm}$. $\mathrm{Hg}$, or "effective" alveolar-mean capillary oxygen tension gradient.

$S_{0} \cdot-\bar{S} v=$ Difference in oxygen saturation between blood leaving the alveolar capillaries and mixed venous blood, or "effective" capillary-mixed venous difference in oxygen saturation.

Max. $\mathrm{D}_{\mathrm{O}_{2}}=$ Maximal diffusing capacity for oxygen.

Per cent of predicted normal maximal $\mathrm{D}_{\mathrm{O}_{2}}=\frac{\text { Observed } \mathrm{D}_{\mathrm{O}_{2}} \times 100}{\text { Predicted normal } \max . \mathrm{D}_{\mathrm{O}_{2}}}$.

in Table III) is often less than $6 \mathrm{~mm} . \mathrm{Hg}$ and hence too small to determine without a large percentile error. In the 6 patients studied pre- operatively at rest, $\mathrm{P}_{\Delta}{ }^{\circ}-\mathrm{Pc}^{\bullet}$ ranged between 14 and $47 \mathrm{~mm}$. Hg. In view of these large gradients, there can be little doubt that the corresponding val- 


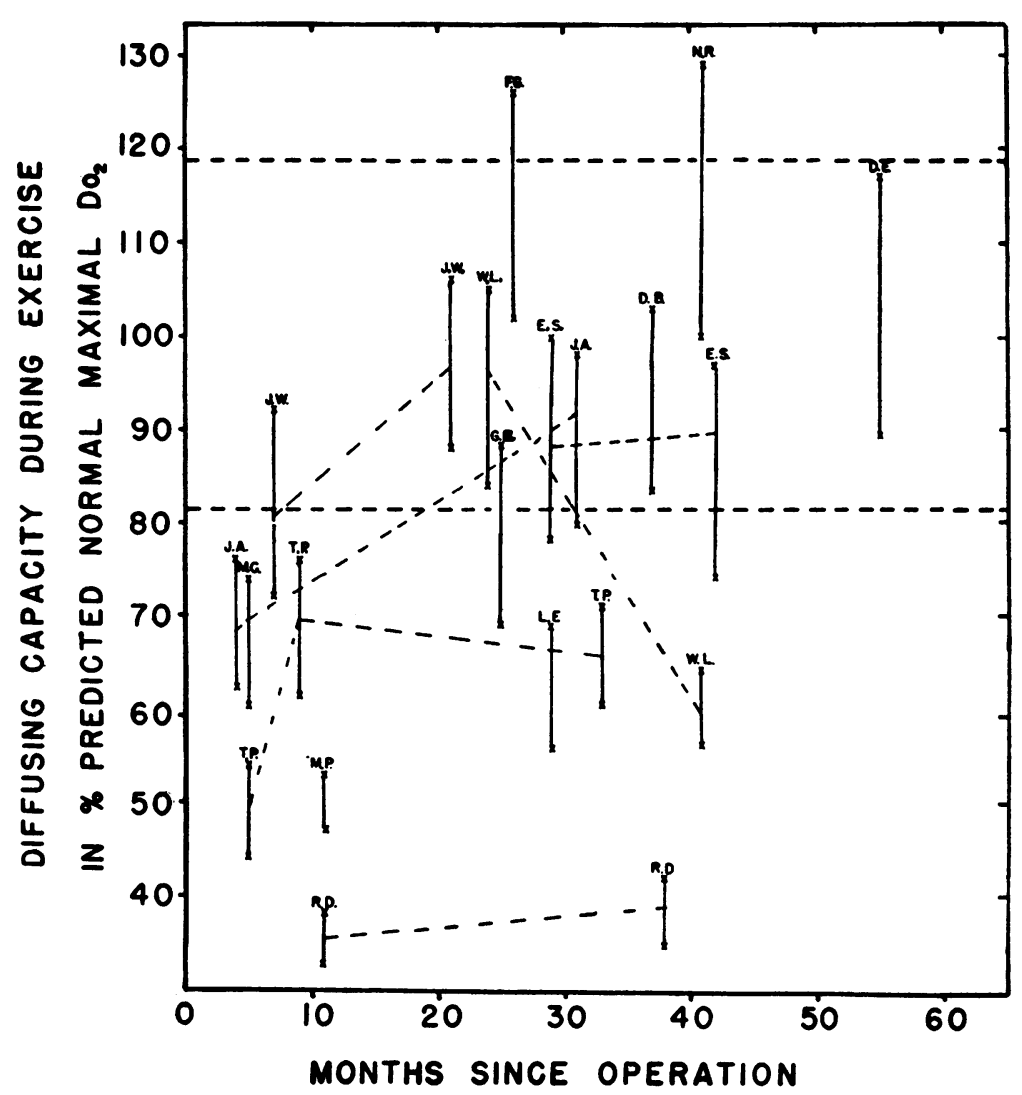

Fig. 1. Diffusing Capacity During Exercise. is Plotted Against the Number of Months Since Operation

The vertical lines indicate the range within which each diffusing capacity value falls, based on calculations using an extreme range of assumed values for mixed venous blood (see text). The results of successive studies on the same patient are connected by broken lines. The horizontal broken lines enclose a range of one standard deviation above and below the predicted normal value (100 per cent). Note that the ordinate scale does not begin at zero.

ues for diffusing capacity at rest were abnormally low."

When the patients who were studied preoperatively at rest had additional studies postoperatively during exercise, there was a striking increase in diffusing capacity in every case. There was no correlation between the values obtained pre-operatively at rest and those obtained post-operatively during exercise. Clinically all patients were markedly improved after operation and had greatly increased exercise tolerance. ${ }^{5}$

4 Furthermore, by the criterion used in a previous publication (12) all these determinations at rest would be considered low.

5 R. D. died suddenly at home $4 \frac{1}{2}$ years after valvulotomy. The $x$-ray picture of the chest had for several

\section{DISCUSSION}

The patients whose diffusing capacities approached the maximal values for normal people must have been both close to normal and close to maximal with respect to diffusion. The fact that they were close to normal indicates that extensive lesions of the pulmonary membrane probably were not present at the time of study. The fact that they were close to maximal indicates that the determination of the maximal, or nearly maximal, diffusing capacity is technically feasible in at least some patients who have had mitral stenosis.

years shown multiple nodular densities indicating structural changes in the lungs which may have been related to the rheumatic process. 
This is of particular interest because the level of exercise which the patients performed was less than that which is required of normal people in obtaining maximal values for diffusing capacity, and the patients' cardiac output values were probably considerably below those of normal persons during the determination of the maximal diffusing capacity. These considerations suggest that the increased pulmonary capillary pressure and/or other hemodynamic alterations in the patients with mitral stenosis tend to increase the proportion of pulmonary capillaries perfused at a given level of cardiac output.

The diffusing capacities which were below normal during exercise might have been low because of structural changes in the diffusing surface or because many of the pulmonary capillaries were not perfused with blood under the conditions of the study. A choice between these alternatives is difficult to make in the case of the moderately low values, but the very low values obtained in patients M. P. and R. D. probably reflect extensive structural damage to the diffusing surface.

Although the factors causing the low pre-operative diffusing capacities at rest cannot all be evaluated, the subsequent post-operative finding of considerably higher values during exercise suggests that some of the factors were reversible. On theoretical grounds it seems possible that the low preoperative diffusing capacities might have been related to low cardiac output, high critical closing pressure of small pulmonary vessels (12), or subclinical pulmonary edema-all potentially reversible.

With respect to the selection of patients for surgery, the experience with this small group indicates that striking clinical improvement from valvulotomy may be obtained even in patients with severe impairment of diffusion. Normal people have a large reserve of diffusing capacity which is required only during very heavy exercise. The limitation of exercise tolerance in patients with mitral stenosis reduces the need for this reserve. Impairment of diffusion therefore appears to be of secondary importance in this group of patients.

\section{SUMMARY}

1. Studies of pulmonary function are reported in 14 patients on whom mitral valvulotomy was performed 5 to 55 months previously. Pulmonary ventilation, intrapulmonary distribution of blood and gas, and diffusing capacity were measured. Findings were related to pre-operative studies previously reported.

2. Although significant incapacity had existed over a period of years pre-operatively, approximately half of the patients showed post-operative diffusing capacities during exercise which were within one standard deviation of the predicted normal values for maximal diffusing capacity. The other patients showed moderate to severe lowering of diffusing capacity during exercise.

3. The patients with diffusing capacities during exercise which were normal probably did not have extensive structural changes in the pulmonary membrane. The 2 with very low values probably did have extensive structural changes. Intermediate values could not be interpreted.

4. All 6 of the patients who were studied preoperatively at rest showed low diffusing capacities. Since all were greatly improved following mitral valvulotomy, a low pre-operative diffusing capacity is not considered a contraindication to surgery.

\section{ACKNOWLEDGMENT}

The authors wish to acknowledge the continued interest of Dr. E. Cowles Andrus, who made possible most of the long term follow-up studies.

\section{REFERENCES}

1. Parker, F., Jr., and Weiss, S., The nature and significance of the structural changes in the lungs in mitral stenosis. Am. J. Path., 1936, 12, 573.

2. Larrabee, W. F., Parker, R. L., and Edwards, J. E., Pathology of intrapulmonary arteries and arterioles in mitral stenosis. Proc. Staff Meet., Mayo Clin., 1952, 24, 316.

3. Henry, E. W., The small pulmonary vessels in mitral stenosis. Brit. Heart J., 1952, 14, 406.

4. Welch, K. J., Johnson, J., and Zinsser, H., The significance of pulmonary vascular lesions in the selection of patients for mitral valve surgery. Ann. Surg., 1950, 132, 1027.

5. Curti, P. C., Cohen, G., Castleman, B., Scannell, J. G., Friedlich, A. L., and Myers, G. S., Respiratory and circulatory studies of patients with mitral stenosis. Circulation, 1953, 8, 893.

6. Dexter, L., Pathologic physiology of mitral stenosis and its surgical implications. Bull. New York Acad. Med., 1952, 28, 90. 
7. Draper, A., Heimbecker, R., Daley, R., Carroll, D., Mudd, G., Wells, R., Falholt, W., Andrus, E. C., and Bing, R. J., Physiologic studies in mitral valvular disease. Circulation, 1951, 3, 531.

8. Werkö, L., Biörck, G., Crafoord, C., Wulff, H., Krook, H., and Eliasch, H., Pulmonary circulatory dynamics in mitral stenosis before and after commissurotomy. Am. Heart J., 1953, 45, 477.

9. Ferrer, M. I., Harvey, R. M., Wylie, R. H., Himmelstein, A., Lambert, A., Kuschner, M., Cournand, A., and Richards, D. W., Circulatory effects of mitral commissurotomy with particular reference to selection of patients for surgery. Circulation, $1955,12,7$.

10. Judson, W. E., Hatcher, J. D., Hollander, W., and Halperin, M. H., The effects of mitral valvuloplasty on cardiovascular and renal function at rest and during exercise. J. Clin. Invest., 1955, 34, 1297.

11. Riley, R. L., Shepard, R. H., Cohn, J. E., Carroll, D. G., and Armstrong, B. W., Maximal diffusing capacity of the lungs. J. Applied Physiol., 1954, 6, 573.

12. Carroll, D., Cohn, J. E., and Riley, R. L., Pulmonary function in mitral valvular disease: Distribution and diffusion characteristics in resting patients. J. Clin. Invest., 1953, 32, 510.

13. Blount, S. G., Jr., McCord, M. C., and Anderson, L. L., The alveolar-arterial oxygen pressure gradient in mitral stenosis. J. Clin. Invest., 1952, 31, 840.
14. Williams, M. H., Jr., Pulmonary function studies in mitral stenosis before and after commissurotomy. J. Clin. Invest., 1953, 32, 1094.

15. Baldwin, E. deF., Cournand, A., and Richards, D. W., Jr., Pulmonary insufficiency. I: Physiological classification, clinical methods of analysis, standard values in normal subjects. Medicine, 1948, 27, 243.

16. Armstrong, B. W., Unpublished line charts.

17. Riley, R. L., and Cournand, A., "Ideal" alveolar air and the analysis of ventilation perfusion relationships in the lungs. J. Applied Physiol., 1949, 1, 825.

18. Riley, R. L., and Cournand, A., Analysis of factors affecting partial pressures of oxygen and carbon dioxide in gas and blood of lungs: Theory. J. Applied Physiol., 1951, 4, 77.

19. Riley, R. L., Cournand, A., and Donald, K. W., Analysis of factors affecting partial pressures of oxygen and carbon dioxide in gas and blood of lungs : Methods. J. Applied Physiol., 1951, 4, 102.

20. Lilienthal, J. L., Jr., Riley, R. L., Proemmel, D. D., and Franke, R. E., An experimental analysis in man of the oxygen pressure gradient from alveolar air to arterial blood during rest and exercise at sea level and at altitude. Am. J. Physiol., 1946, 147, 199.

21. Cohn, J. E., Carroll, D. G., Armstrong, B. W., Shepard, R. H., and Riley, R. L., Maximal diffusing capacity of the lung in normal male subjects of different ages. J. Applied Physiol., 1954, 6, 588. 